\title{
Periplasmic aminopeptidase and alkaline phosphatase activities in a marine bacterium: implications for substrate processing in the sea
}

\author{
Josefina Martinez*, Farooq Azam \\ Marine Biology Research Division, Scripps Institution of Oceanography, University of California, San Diego, \\ La Jolla, California 92093-0202, USA
}

\begin{abstract}
The occurrence of periplasmic aminopeptidase and alkaline phosphatase (APase) was studied in a Gram-negative bacterium (designated S8) isolated from the surface waters off the Southern California coast. We tested the hypothesis that processing of polymeric substrates (e.g. protein) by marine bacteria involves ectohydrolases both on the cell surface and in the periplasmic space but small substrates (e.g. sugar phosphates) are hydrolytically processed only in the periplasm Optimum conditions for cold osmotic shock were established to maximize protein release $(14.3 \pm 2.2 \%$ of the total cellular protein) without significant release of cytoplasmic protein (using glucose-6phosphate dehydrogenase as cytoplasmic indicator). Only $4.2 \pm 4.0 \%$ aminopeptidase but $63.4 \pm 4.8 \%$ APase was shockable. An additional $17 \%$ APase was released by a second shock. Although not shockable, the majority of aminopeptidase $(67 \%$ ) was periplasmic (not accessible to bovine serum albumin (BSA)]; $33 \%$ was considered surface bound (accessible to BSA). The cellular distribution of aminopeptidase activity is consistent with the model that cell surface aminopeptidase generate oligomers which diffuse into the periplasm where they are monomerized by the high aminopeptidase activity in an environment where the monomers may interact with substrate binding protein or directly with the permeases. While most APase was periplasmic we were unable to determine whether any APase was also present on the cell surface. In S8 the fluorogenic substrates (leucine AMC and MUF-P) did not measure the cytoplasmic enzymes but did measure periplasmic activities. If these results can be extrapolated to natural marine assemblages, then ectoenzyme measurements using the fluorogenic substrates represent the sum of cell surface and periplasmic (but not cytoplasmicl pools of the enzymes. Since ectohydrolase distribution may be important in substrate processing and bacteria-organic matter coupling, future environmental studies of ectoenzymes should distinguish between the 'surface ectoenzymes' and 'periplasmic ectoenzymes'
\end{abstract}

\section{INTRODUCTION}

Extracytoplasmic processing of organic nutrient molecules is a central unsolved problem in understanding bacteria-organic matter coupling in the pelagic ocean. Only a small fraction of the organic matter utilizable by bacteria is in the form of 'direct substrates' (a term coined by Lancelot et al. (1989) to describe the substrates which can be directly taken up by bacteria); most polymeric utilizable organic matter (such as proteins, polysaccharides and nucleic acids)

- Permanent address: Department of Microbiology, University of Barcelona, Avda. Diagonal 645, E-08028 Barcelona, Spain must first be hydrolysed to monomers before their transmembrane transport (Rodgers 1961, Hollibaugh \& Azam 1983, Somville \& Billen 1983, Hoppe et al. 1988, Chróst 1989). Some small but charged molecules such as sugar phosphates and nucleotides also require hydrolytic dephosphorylation prior to uptake (Ammerman \& Azam 1985). An adaptive challenge for bacteria in the pelagic realm is to hydrolyse the 'potential substrates' and do so in such a manner that the products of hydrolysis can be efficiently transported into the cell with minimum diffusive losses.

Ectoenzymes of bacteria are believed to be responsible for substrate hydrolyses (Chróst 1990). In view of the importance of ectoenzymes in bacteria-organic 
matter coupling their study in relation to organic matter utilization by bacteria has become a highly dynamic field of research (Hollibaugh \& Azam 1983. Hoppe 1983, Somville \& Billen 1983, Chróst et al. 1986, Chróst \& Overbeck 1987, Hoppe et al. 1988, Billen 1991, Chróst 1991). While a large body of information now exists on spatial and temporal patterns of ectoenzyme activities in the sea, our knowledge is still quite limited on how the bacterial cells process the potential substrates and how the ectoenzymes (cell surface and periplasmic) play a role in nutrient acquisition. There is a need to find out the cellular location, kinetic characteristics and environmental regulation of the expression of the ectoenzymes as well as their interactions with other components of the nutrient acquisition systems such as substrate binding proteins and permeases. These highly complex issues may appear intractable, particularly when considered in an ecosystem context, but their eventual resolution is necessary if we are to understand bacteria-organic matter coupling at a mechanistic level.

Hollibaugh \& Azam (1983) tested the hypothesis that a biochemical strategy of pelagic bacteria for processing potential substrates is to have cell-surfaceassociated hydrolases rather than to release the enzymes into seawater. They found that in natural assemblages of bacteria in coastal waters most of the aminopeptidase activity was indeed cell associated. This obsevation now appears to be generally valid (Hoppe 1983, Vives-Rego et al. 1985, Chróst \& Overbeck 1987, Rosso \& Azam 1987, Chróst 1991, Hoppe 1991) although exceptions have also been reported (Kim \& ZoBell 1974, Little et al. 1979, Meyer-Reil et al. 1981). Further, Hollibaugh \& Azam (1983) found a tight coupling between protein hydrolysis and the uptake of hydrolysis products. While the biochemical mechanism of hydrolysis-uptake coupling is not clear, one might hypothesize that in Gram-negative bacteria the periplasmic enzymes and/or substrate binding proteins provide a link between the cell surface ectoenzymes and the permeases located in the cytoplasmic membrane. The polymeric substrates such as proteins and polysaccharides are too large to enter the periplasmic space and must first be hydrolysed to monomers or oligomers. Monomers may diffuse into the periplasmic space and interact with the permeases (directly or via binding proteins). Alternatively, hydrolysis by cell surface endoproteases may produce oligomers small enough to diffuse across the outer membrane and be further processed by periplasmic exoproteases to amino acids which can then interact with the permeases. Thus, ectoproteolytic processing of potential substrates may involve activities both on the cell surface and in the periplasmic space (Chróst 1990), but this has not been examined in marine bacteria.
The processing of potential substrates small enough to diffuse through the outer membrane (e.g. sugar phosphates and nucleotides) might, unlike the polymers, be restricted to the periplasmic space. One might speculate, then, that enzymes such as alkaline phosphatase and 5 '-nucleotidase in pelagic marine bacteria would occur only in the periplasmic space.

The purpose of this study was to test the hypothesis that substantial fractions of ectoprotease activity in marine bacteria occur both on the cell surface and in the periplasmic space. Further, we attempted to test whether alkaline phosphatase (APase) activity was restricted to the periplasmic space. This study was done using a Gram-negative bacterial strain (designated S8) which we have isolated from California (USA) coastal waters. S8 can constitute a significant (at times dominant) species of the Scripps pier (California). Hybridization of total community DNA with an oligonucleotide probe, based on S8 16S rRNA sequence data, showed that $\mathrm{S} 8$ is commonly detectable as a significant, even dominant, component of the eubacterial assemblage (Rehnstam et al. 1993). In order to determine the occurrence of aminopetidase and alkaline phosphatase in the periplasmic space we chose to use cold osmotic shock. The 'standard method' of Neu \& Heppel (1965) was developed for enteric bacteria and it may not be suitable for bacteria growing in high salt concentrations. We first established conditions suitable for cold osmotic shock for marine bacteria. Further, since we wanted to distinguish periplasmic enzymes from other pools of the enzymes, it was necessary to verify that the conditions for the cold osmotic shock did not cause the release of cytoplasmic pools.

\section{MATERIALS AND METHODS}

Bacterial strain. We used a marine bacterium isolated from the Scripps pier and designated S8. It is a Gram negative rod, motile by a polar flagellum. Its protein content is $0.42 \mathrm{~g} \mathrm{~g}^{-1}$ dry weight. S8 has a doubling time of $30 \mathrm{~min}$ in ZoBell medium $15 \mathrm{~g}$ peptone, $1 \mathrm{~g}$ yeast extract in $1 \mathrm{l}$ of $0.45 \mu \mathrm{m}$ Millipore filtered seawater, autoclaved at $121^{\circ} \mathrm{C}$ for $30 \mathrm{~min}$ ) at $18^{\circ} \mathrm{C}$ and $270 \mathrm{~min}$ at $5{ }^{\circ} \mathrm{C}$. Its maximal temperature for growth is $29^{\circ} \mathrm{C}$.

Experimental procedure. Cultures were grown in ZoBell medium at 16 to $18{ }^{\circ} \mathrm{C}$ on a rotary shaker. Cells from ZoBell agar plates ( $1.5 \% \mathrm{wt} / \mathrm{vol}$ agar, Difco) were grown overnight in liquid culture and subcultured the following day into fresh liquid medium. The cells were harvested in late exponential phase $(8$ to $12 \mathrm{~h}$; final culture density of $5 \times 10^{8}$ cells $\mathrm{ml}^{-1}$ ) by centrifugation $(6000 \times \mathrm{g}, 10 \mathrm{~min})$. They were washed twice with salt medium (SM; $200 \mathrm{mM} \mathrm{NaCl}, 10 \mathrm{mM}$ $\mathrm{KCl}, 10 \mathrm{mM} \mathrm{CaCl}_{2}, 50 \mathrm{mM}$ Tris-HCl, $19 \mathrm{mM} \mathrm{NH}_{4} \mathrm{Cl}$ 
and $50 \mathrm{mM} \mathrm{MgCl}_{2}$ in deionized $\mathrm{H}_{2} \mathrm{O}, \mathrm{pH} 8.0$ ) for subsequent experiments.

Cold osmotic shock. We optimized the conditions for cold osmotic shock by modifying the 'standard' (e.g. Neu \& Heppel 1965) procedure to make it suitable for the marine isolate S8. The 'standard' procedure has the following steps which we have sought to optimize as indicated. (1) Cells are suspended in a hyperosmotic medium ('suspension medium'). Sucrose solution is used but mineral salts have been used instead (Geesey \& Morita 1981) for a marine bacterium, ANT 300. We considered that the suspension medium for marine bacteria may require both sucrose and salt in order to optimize cell integrity. (2) Cells are separated from the suspending medium by centrifugation. (3) The pellet is resuspended in cold 'shock medium' to cause osmotic shock, thus releasing periplasmic 'shockable' proteins. The shock medium is typically a buffer but we considered that salt may be necessary to maintain the integrity of marine bacteria and prevent the release of cytoplasmic proteins. (4) The shocked cells are sedimented to isolate the shockable proteins which should be in the supernatant ('shock fluid'). We varied the composition of the suspending and shock media and determined the efficiency of release of total protein, aminopeptidase and APase into the shock fluid. In order to check whether there had been a release of cytoplasmic protein into the shock fluid, glucose-6-phosphate dehydrogenase (G6PDH) was used as marker

Protein determination. Protein concentration in bacteria and in the shock fluid was determined by the bicinchoninic acid method (Smith et al. 1985) using a commercial reagent (BCA Protein Assay Reagent; Pierce Chemical Co.).

Enzyme assays. We assayed G6PDH by following the rate of NADP reduction. Samples in $0.05 \mathrm{M}$ Tris(hydroxymethyl) amino methane (Tris) or in SM ( $\mathrm{pH} 8.0)$ were added with $3.33 \mathrm{mM}$ glucose-6P, $0.1 \%$ bovine serum albumin (BSA; Sigma), $80 \mu$ M NADP and $3.3 \mathrm{mM} \mathrm{MgCl}_{2}$ final concentrations. The mixture was incubated at room temperature $\left(18\right.$ to $\left.20^{\circ} \mathrm{C}\right)$ and the reaction was stopped at various time points by placing the samples on ice. The subsamples were then centrifuged $(16000 \times \mathrm{g}, 10 \mathrm{~min})$ and the absorbance of the supernatant was measured at $340 \mathrm{~nm}$ in a spectophotometer. In cell free extracts the assay was done directly in a cuvette by measuring the increase of absorbance with time. The G6PHD activity was calculated as nmol NADPH produced $\mathrm{ml}^{-1} \mathrm{~h}^{-1}$.

APase activity was assayed using the fluorogenic substrate methyl umbelliferyl phosphate (MUF-P). This substrate is enzymatically hydrolysed with release of the highly fluorescent product methylumbelliferon (MUF) (Hoppe 1983). The substrate, dissolved in methylcellosolve, was added directly to the sample in a fluorometer cuvette, at $20 \mu \mathrm{M}$ or $40 \mu \mathrm{M}$ final concentration. Increase in fluorescence with time was measured (excitation $365 \mathrm{~nm}$; emission $460 \mathrm{~nm}$ ) in a Hoefer TKO 100 spectrofluorometer at room temperature. A standard curve was made with each run using a range of concentrations of MUF (Sigma). The enzyme activity was expressed in terms of the rate of MUF production.

Aminopeptidase activity was assayed as the hydrolysis rate of leucine-amino methyl-coumarin (leu-AMC, Sigma; Hoppe et al. 1988). The measurement procedure was the same as for APase, and the activity was measured as the rate of AMC production.

Enumeration of bacteria. Bacterial counts were performed by epifluorescence microscopy after staining the cells with 4,6-diamidino-2-phenyl indole (DAPI) (Porter \& Feig 1980).

Cell viability. Bacterial viable counts were determined on serial dilutions of cells in SM, plated on ZoBell agar. Plates were incubated at $16^{\circ} \mathrm{C}$ and the colonies counted at 24 and $48 \mathrm{~h}$.

\section{RESULTS AND DISCUSSION}

\section{Optimum conditions for osmotic shock}

Our objective was to release aminopeptidase and APase from the periplasm without releasing cytoplasmic or cell-surface activities of these enzymes. We first determined whether G6PDH was suitable as a marker for release of cytoplasmic enzymes. We then determined conditions for distinguishing between shockable and simply 'washable' enzyme activities. Finally, we determined the concentration of SM, sucrose and ethylenediaminetetraacetic acid (EDTA) as well as physical treatments to optimize periplasmic enzyme release while minimizing the release of cytoplasmic enzymes using G6PDH as marker

Suitability of G6PDH as a cytoplasmic marker. G6PDH has been used previously as cytoplasmic marker in Escherichia coli (Calcott \& Macleod 1975), and its appearance in the shock fluid will indicate a breach in membrane integrity. Table 1 shows that cell suspension in SM did not have measurable G6PDH activity, but that $0.05 \mathrm{M}$ Tris $\mathrm{pH} 8$ had high G6PDH activity. Cell disruption by Tris apparently exposes G6PDH to the substrate, and the appearence of G6PDH activity should therefore indicate cell disruption. Most G6PDH in Tris treated cells appeared trapped within the cells (97\% could be sedimented by centrifuging at $16000 \times$ $g$ for 10 min; Table 1 ) making it necessary to measure it in cell suspensions rather than the shock fluid.

'Washable' enzyme activity. A large fraction (63.3 \pm $9.1 \%$ ) of the aminopeptidase in intact cells in late 
Table 1. Glucose 6-P dehydrogenase (G6PDH) activity (measured as rate of NADPH hydrolysis) of S8 suspended in salt medium (SM) and in $50 \mathrm{mM}$ Tris. The enzyme was also assayed in the supernatant after centrifugation of the cell suspension at $16000 \times \mathrm{g}$ for $10 \mathrm{~min}$. See text for composition of the medium

\begin{tabular}{|lcc|}
\hline Medium & \multicolumn{2}{c|}{$\begin{array}{c}\text { G6PDH activity } \\
\text { (nmol NADPH ml }\end{array}$} \\
& Cell suspension & Supernatant \\
\hline SM & 0.0 & 0.0 \\
Tris & 129.0 & 4.5 \\
\hline
\end{tabular}

exponential cultures of S8 was present in solution (Table 2). In addition, some aminopeptidase activity may have been loosely bound to the cell surface. In order to ensure that the shock fluid was not contaminated by loosely bound enzymes we washed the cells with SM until the supernatant was aminopeptidasefree. Two washes were sufficient (Table 2). In sharp contrast to aminopeptidase, a very small fraction (generally $<1 \%$ ) of APase activity appeared in the growth medium and, further, no APase activity was released during the washes.

Optimum concentrations of SM and sucrose in the suspending medium. The pelleted cells of S8 were gently resuspended in $20 \%$ sucrose solution prepared in $0 \%$ to $100 \%$ of $\mathrm{SM} \mathrm{pH} 8$ but in the absence of $\mathrm{MgCl}_{2}$. EDTA (10 mM) was present in all manipulations. After $15 \mathrm{~min}$ at room temperature, the mixture was centrifuged for $15 \mathrm{~min}$ at $16000 \times \mathrm{g}$ at $4{ }^{\circ} \mathrm{C}$. The supernatant was removed and the pellet was rapidly resuspended in cold SM. The suspension was incubated in an ice bath for $10 \mathrm{~min}$ and centrifuged for 15 min at $16000 \times g$ at $4{ }^{\circ} \mathrm{C}$. The supernatant (shock fluid) was recovered and kept on ice until enzyme assays were run. Table 3 shows that significant amounts of G6PDH were released at all concentrations of SM tested other than $100 \%$. Even $75 \%$ SM led to high

Table 2. Release of aminopeptidase and alkaline phosphatase (APase) activities into the growth medium and during washing of cell pellets. Values represent activity in supernatant as percentage of activity in the cell suspension. Numbers in parentheses are $\pm \mathrm{SD}_{i} \mathrm{n}=$ number of experiments. $\mathrm{nd}=$ not determined

\begin{tabular}{|lcc|}
\hline & Aminopeptidase, \% & APase, \% \\
\hline $\begin{array}{l}\text { Release in culture } \\
\text { medium }\end{array}$ & $63.3(9.1), \mathrm{n}=7$ & $0.6(0.9), \mathrm{n}=7$ \\
$\begin{array}{l}\text { Release during } \\
\text { first wash }\end{array}$ & $9.9(2.1), \mathrm{n}=4$ & $0.0, \mathrm{n}=2$ \\
$\begin{array}{l}\text { Release during } \\
\text { second wash }\end{array}$ & $1.6(1.0), \mathrm{n}=3$ & $\mathrm{nd}$ \\
\hline
\end{tabular}

Table 3. Glucose 6-P dehydrogenase (G6PDH) activity after treatment of $\mathrm{S} 8$ suspension with $20 \%$ sucrose prepared in different concentrations of salt medium (SM). See text for composition of SM

\begin{tabular}{|cc|}
\hline$\% \mathrm{SM}^{\mathrm{d}}$ & $\begin{array}{c}\text { G6PDH activity } \\
\text { (nmol NADPH ml }\end{array}$ \\
\hline 0 & 3.00 \\
25 & 2.04 \\
50 & 1.12 \\
75 & 0.88 \\
100 & 0.0 \\
${ }^{2}$ SM was diluted with $0.05 \mathrm{M}$ Tris, $\mathrm{pH} 8$ \\
\hline
\end{tabular}

G6PDH release. We therefore concluded that $100 \%$ $\mathrm{SM}$ in the suspending medium was required for cell integrity. Also, $20 \%$ sucrose in $100 \% \mathrm{SM}$ did not cause a significant release of APase or aminopeptidase; only $1.4 \%(n=4$; $\mathrm{SD}= \pm 0.9 \%)$ aminopeptidase and $3.5 \%(n=4 ; S D= \pm 2.0 \%)$ APase was found in the supernatant after sedimenting the cells.

Effect of EDTA. We determined the effect of the presence of EDTA in the suspending medium on the release of protein and APase in the shock fluid. These were released even in the absence of EDTA but the release was $20 \%$ and $25 \%$ higher, respectively, in the presence of $10 \mathrm{mM}$ EDTA (not shown). Higher concentrations of EDTA did not increase the release. Therefore, $10 \mathrm{mM}$ EDTA is optimum in the suspending medium.

Salt concentration of the shock medium. The cells which had been exposed to the above suspending medium were pelleted and resuspended in shock media consisting of a range of SM concentrations from $0 \%$ to $100 \%$. Table 4 shows that at SM concentrations lower than $100 \%$ there was significant release of G6PDH indicating cell disruption. The fraction of total G6PDH that appeared to be 'trapped' in the disrupted cells

Table 4. Glucose 6-P dehydrogenase (G6PDH) activity of S8 after osmotic shock at different concentrations of cold salt medium (SM). See text for composition of the medium

\begin{tabular}{|c|c|c|}
\hline \multirow[t]{2}{*}{$\% \mathrm{SM}^{\mathrm{a}}$} & \multicolumn{2}{|c|}{$\begin{array}{c}\text { G6PDH activity } \\
\text { (nmol NADPH ml }{ }^{-1} \text { min }^{-1} \text { ) }\end{array}$} \\
\hline & Total & $\%$ in supernatant ${ }^{b}$ \\
\hline 100 & 0.0 & 0.0 \\
\hline 75 & 4.8 & 0.7 \\
\hline 50 & 7.7 & 0.5 \\
\hline 25 & 14.8 & 3.3 \\
\hline 0 & 20.9 & 38.5 \\
\hline \multicolumn{3}{|c|}{ "SM was diluted with $0.05 \mathrm{M}$ Tris ( $\mathrm{pH} 8$ ) } \\
\hline \multicolumn{3}{|c|}{$\begin{array}{l}{ }^{\mathrm{b}} \mathrm{G} 6 \mathrm{PDH} \text { activity in supernatant as percent of total in cell } \\
\text { suspension }\end{array}$} \\
\hline
\end{tabular}


(sedimented at $16000 \times g$ for $10 \mathrm{~min}$ ) increased with increasing SM concentrations, implying more severe membrane disruption as a function of decreasing salt concentration. We decided to use $100 \% \mathrm{SM}$ as shock medium since it was necessary for preventing the release of cytoplasmic proteins using $\mathrm{G} 6 \mathrm{PDH}$ as indicator.

Sucrose concentration of the shock medium. We determined the effect of varying sucrose concentration in the suspending medium on the release of protein by osmotic shock. Fig. 1 shows that (1) sucrose was necessary for releasing protein; and (2) protein release increased sharply with increase in sucrose concentration up to $40 \%$ sucrose (which was the highest concentration tested). No measurable G6PDH was detected at sucrose concentrations up to $20 \%$ but there was significant release at $40 \%$ sucrose. We therefore concluded that $20 \%$ sucrose was optimum

Optimum procedure for osmotic shock. In view of the above results, the optimum conditions for cold osmotic shock for S8 are: The suspending medium should contain $20 \%$ sucrose in $100 \% \mathrm{SM}$ containing $10 \mathrm{mM}$ EDTA. The 'shock medium' should contain $100 \%$ SM. The presence of $100 \% \mathrm{SM}$ in both the suspending and shock media is necessary for cell integrity. Using these conditions we could budget the inventories of the activities of aminopeptidase and APase. Loss of enzyme activities from the cells was found to be accounted for by the enzyme activity in the shock fluid. This was determined by comparing the enzyme activities in the initial cell suspension and the resuspended cells after the shock (not shown). Cell viability was determined by plate counts after the osmotic shock and was found to be 80 to $90 \%$ of the viability of the initial cell suspension.

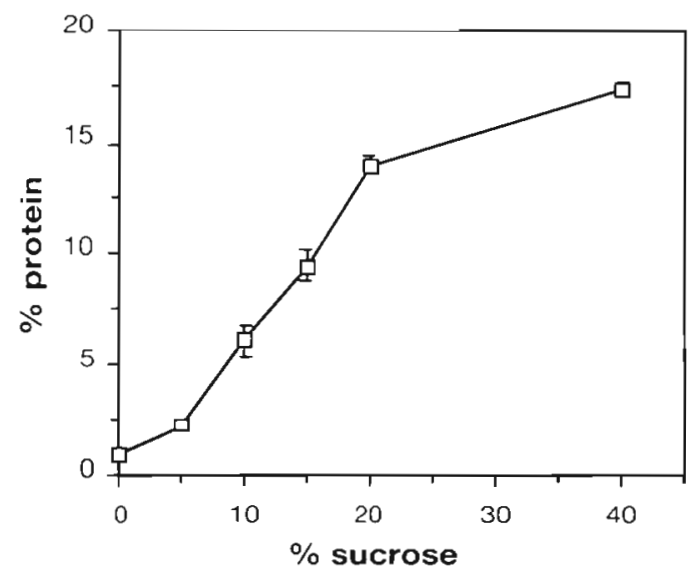

Fig. 1. Effect of varying sucrose concentration during cold osmotic shock on the release of protein in the shock fluid. Sucrose solutions were prepared in $100 \%$ SM, pH 8 . Release of protein is given as percentage of the total cellular protein. Bars represent standard deviation of the mean; $n=2$. See text for conditions for the cold osmotic shock

\section{Comparison with other osmotic shock procedures}

The osmotic shock conditions found to be optimum by us for $\mathrm{S} 8$ are different from those used in other studies with marine bacteria (Geesey \& Morita 1981, Albertson et al. 1990a, b). These authors implicitly assumed that transferring marine bacteria from high salt medium to a hypotonic medium will release periplasmic proteins. Geesey \& Morita (1981) were the first to adapt the cold osmotic shock procedure for use with marine bacteria. They osmotically shocked the isolate ANT 300 by suspending the cells from full strength artificial seawater (ASW) medium (comparable to seawater osmolarity) to $1 / 4$ strength ASW. In our experiments with S8, however, transfer of cells from $100 \%$ SM to $25 \%$ SM caused the release of a large fraction of G6PDH, indicating release of cytoplasmic proteins. Albertson et al. (1990b) osmotically shocked a marine vibrio by transferring the cells from full strength seawater osmolarity into distilled water. These studies did not seek to prevent the release of cytoplasmic proteins or to optimize the release of periplasmic proteins, and in this respect our goal differed from theirs. We wanted to release periplasmic proteins uncontaminated by the cytoplasmic proteins. Our results (above) show that in order to release the periplasmic proteins sucrose was necessary in the suspending medium and that $20 \%$ sucrose was optimum, as was previously found by Neu \& Heppel (1965) for Escherichia coli. Further, in order to minimize the release of cytoplasmic protein the presence of $100 \%$ SM both during sucrose treatment and during the shock was essential.

\section{Protein, aminopeptidase and APase release by cold osmotic shock}

Using the above procedure, we determined what fraction of the cellular protein was released from $\mathrm{S} 8$ by osmotic shock. The results of 8 different experiments (Table 5) show that $14.3 \pm 2.2 \%$ of the total cellular protein was released. This release of $\mathrm{S} 8$ periplasmic protein is in the range found by others working with enteric bacteria and using different techniques (Neu \& Heppel 1965, Ames et al. 1984). No comparable data exist for marine bacteria. Geesey \& Morita (1981) used an osmotic shock procedure (above) quite different from ours on a marine vibrio, ANT 300 , and found that $<1 \%$ of the cellular protein was released. We do not know whether the difference between their release and ours was due to the differences in the species of bacteria used or differences in the procedures.

The percent shockable activity was dramatically different between aminopeptidase and APase. Only $4.2 \pm 4.0 \%$ aminopeptidase was shockable while 
Table 5. Protein, protease and alkaline phosphatase (APase) activities released into shock fluid as percentage of intact cells

\begin{tabular}{cccc|}
\hline Expt & \multicolumn{3}{c|}{$\begin{array}{c}\% \text { Release } \\
\text { Protease }\end{array}$} \\
\cline { 1 - 2 } 1 & Protein & APase \\
2 & 15.6 & 0.4 & 67.2 \\
3 & 16.5 & 8.1 & 67.0 \\
4 & 10.0 & 0.2 & 50.4 \\
5 & 14.4 & 5.2 & 66.0 \\
6 & 12.0 & 1.4 & 67.0 \\
7 & 15.4 & 1.6 & 62.4 \\
8 & 14.4 & 11.5 & 66.0 \\
9 & 16.0 & 4.9 & 63.6 \\
10 & - & - & 68.0 \\
11 & - & - & 60.0 \\
12 & - & - & 62.4 \\
Mean & - & - & 61.1 \\
\pm SD & 14.3 & 4.2 & 63.4 \\
\hline
\end{tabular}

$63.4 \pm 4.8 \%$ APase was shockable. Shockable aminopeptidase activity was highly variable while APase showed much less variability. The variability in shockable aminopeptidase activity was not correlated with the total aminopeptidase activity nor with the protein concentration in the intact cells.

\section{Localization of the enzyme activities}

Aminopeptidase. We attempted to distinguish between the distribution of aminopeptidase activity in 3 compartments (cell surface, periplasm and cytoplasm). If leu-AMC did not cross the cytoplasmic membrane then cell disruption should increase aminopeptidase activity by exposing cytoplasmic enzyme to the substrate. We suspended washed S8 cells either in SM (to maintain cell integrity) or $50 \mathrm{mM}$ Tris in distilled water (this treatment disrupts S8 since it exposes G6PDH to exogenous G6P; see above). Cells in Tris had $35 \%$ higher aminopeptidase activity $\left(804 \mathrm{pmol}^{\mathrm{AMC} \mathrm{ml}^{-1}}\right.$ $\min ^{-1}$ ) than those in SM. A control experiment indicated that $50 \mathrm{mM}$ Tris did not influence aminopeptidase assay (not shown). Thus, cell disruption exposed a new pool of aminopeptidase to leu-AMC and we assume that this pool was cytoplasmic. Whether all cells were disrupted was not determined and, thus, we may have underestimated the cytoplasmic amino peptidase activity. The minimum cytoplasmic pool therefore was $[35 /(100+35)]$ $\times 100$ or $26 \%$ of the total cell aminopeptidase (we set the S8 aminopeptidase accessible to leu-AMC in SM at 100 arbitrary units; the cytoplasmic activity would then be 35 arbitrary units). Importantly, the finding that cell disruption exposes a substantial new pool of aminopeptidase to leu-AMC suggests that leu-AMC does not enter $\mathrm{S} 8$ cytoplasm.
We considered that BSA added to cell suspension in SM should compete with leu-AMC but only for the cell surface aminopeptidase; aminopeptidase in the periplasm and the cytoplasm should not be accessible to a molecule as large as BSA (68000 Da). Fig. 2A shows that in intact S8 BSA inhibited leu-AMC hydrolysis by a maximum of $33 \%$ suggesting that $33 \%$ of aminopeptidase activity accessible to leu-AMC was accessible to BSA. The remaining $67 \%$ of aminopeptidase which was accessible to leu-AMC should be in the periplasm. If we added peptides to a cell suspension in SM the peptides will likely penetrate the outer membrane and compete with leu-AMC for cell surface as well as periplasmic aminopeptidases. Fig. 2B shows that addition of $10 \mathrm{mg}$ peptone $\mathrm{ml}^{-1}$ completely inhibited leu-AMC hydrolysis. Thus, the periplasm contained $67 \%$ and the cell surface contained $33 \%$ of the aminopeptidase activity measurable by leu-AMC.
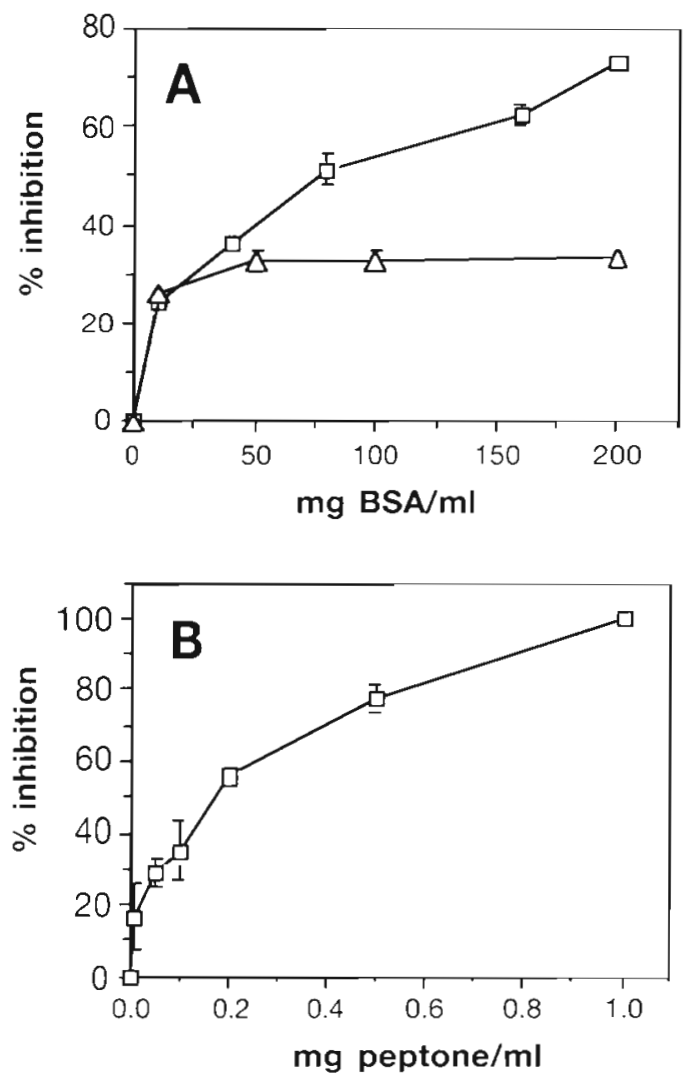

Fig. 2. Inhibition of $S 8$ aminopeptidase activity (expressed as $\%$ of the control) by various concentrations of (A) BSA and (B) peptone. (A) $\triangle$ : S8 cells were suspended in SM and mixed with various concentrations of $B S A$ before measuring arninopeptidase; $\square$ : 58 protease solubilized with $0.2 \%$ Triton $X-100$ and separated from cells by centrifugation. The solubilized fraction was mixed with various concentration of BSA before aminopeptidase assay. (B) S8 cells were suspended in SM, mixed with various concentrations of peptone followed by aminopeptidase assay. See text for aminopeptidase assay conditions 
In a control experiment to ascertain that BSA was indeed able to inhibit all aminopeptidase accessible to it we examined BSA inhibition of soluble aminopeptidase in spent S8 culture supernatant (about $60 \%$ of the aminopeptidase in $\mathrm{S} 8$ cultures grown in ZoBell medium is found in the cell-free supernatant; Table 2). BSA strongly inhibited leu-AMC hydrolysis by the soluble aminopeptidase (Fig. 2A). The inhibition was $75 \%$ at the highest BSA concentration used $(200 \mathrm{mg}$ $\mathrm{ml}^{-1}$ or $2.9 \mathrm{mM}$ ) and higher concentration would likely have caused greater inhibition

Although the largest pool of aminopeptidase was periplasmic (above) little aminopeptidase activity was released by osmotic shock (the shock fluid had only $4.2 \%$ of the activity measurable in intact cells by leuAMC hydrolysis; Table 5). Hence, most aminopeptidase was periplasmic but not shockable. Further, the $33 \%$ of the activity considered to be surface bound was not released by Triton X-100. Vives-Rego et al. (1985) used L-leucyl- $\beta$-naphthylamide as substrate and found that treatment of pelagic assemblages with Triton X-100 released most of the surface aminopeptidase activity. In contrast, we found in 2 separate experiments (but using leu-AMC as substrate) that Triton $\mathrm{X}-100$ released only a negligible fraction $(2.8 \%)$ of aminopeptidase activity of washed S8 cells (Table 6). A control experiment showed that Triton $X-100$ did not measurably affect aminopeptidase assay. It may be that the cell surface aminopeptidase in S8 is tightly bound and is not released by Triton X-100

On the basis of the above findings, we conclude that leu-AMC measures the cell surface as well as the periplasmic aminopeptidase but not the cytoplasmic enzyme activity.

Table 6 . Effect of Triton $X-100$ on the aminopeptidase activity and its release in S8. The cells were grown in ZoBell medium, harvested by centrifugation, washed with SM and suspended in SM before assayed. In Expt 1 aminopeptidase activity was measured after the cell suspension was divided in 2 aliquots. One was incubated with $0.2 \%$ Triton X-100 for $2 \mathrm{~min}$, shaking gently by inversion. The other aliquot was not treated. In Expts 2 and 3 the cell suspension was treated as above. Aliquots were centrifuged $(16000 \times g, 10 \mathrm{~min})$, the supernatants were filtered through $0.2 \mu \mathrm{m}$ Acrodisc (Gelman, low protein binding) and the aminopeptidase activity was measured

\begin{tabular}{|c|c|c|c|}
\hline Expt & $\begin{array}{r}\operatorname{Pr} \\
\text { (nmol }\end{array}$ & $\begin{array}{l}\text { ease activity } \\
\mathrm{MC}^{-1} \mathrm{~min}^{-1} \text { ) }\end{array}$ & $\%$ Soluble \\
\hline 1 & $\begin{array}{l}\text { Cell suspension } \\
\text { Cell suspension }+ \text { Triton } X-100\end{array}$ & $\begin{array}{l}65.3 \\
64.6\end{array}$ & \\
\hline 2 & $\begin{array}{l}\text { Cell suspension } \\
\text { Soluble } \\
\text { Soluble after Triton X-100 }\end{array}$ & $\begin{array}{r}21.1 \\
0.5 \\
0.6\end{array}$ & $\begin{array}{l}2.4 \\
2.8\end{array}$ \\
\hline 3 & $\begin{array}{l}\text { Cell suspension } \\
\text { Soluble } \\
\text { Soluble after Triton X-100 }\end{array}$ & $\begin{array}{r}25.1 \\
0.5 \\
0.7\end{array}$ & $\begin{array}{l}2.0 \\
2.8\end{array}$ \\
\hline
\end{tabular}

Alkaline phosphatase. The activity was considered to be APase rather than nucleotidase because it was strongly inhibited by G6P and $\mathrm{P}_{1}$ (Table 7; Ammerman \& Azam 1985, 1991). In sharp contrast to aminopeptidase activity, the cold osmotic shock released $63.4 \pm$ $4.8 \%$ of the APase activity into the shock fluid. A second cycle of the osmotic shock procedure released another $17 \%(\mathrm{SD}= \pm 0.7 \% ; \mathrm{n}=2)$ of activity. Also in contrast to aminopeptidase activity, resuspension of cells in Tris (to disrupt them) did not cause a measurable increase in APase activity in the suspension; hence the cytoplasmic APase was either a very small fraction of the total cell APase or the cytoplasmic APase was not active under our assay conditions. Thus, the APase activity measurable with MUF-P was dominated by the periplasmic component (about $80 \%$; above) as was the case with aminopeptidase $(67 \%$; above). We did not determine whether the remainder of the APase, in part or whole, was located on the cell surface or whether it was also periplasmic but not shockable.

Utility of cold osmotic shock for studies of periplasmic components in marine bacteria. We have so far worked with only 1 marine isolate. The procedure for cold osmotic shock and the substrate inhibition protocols developed here should also be applicable to other isolates and should thus permit a test of the generality of our conclusions. Further, our osmotic shock procedure should enable studies of the periplasmic components of marine bacteria, including the substrate binding proteins, and their role in nutrient utilization. In principle, the osmotic shock procedure should also be applicable to natural assemblages of marine bacteria, to test whether the biochemical strategies for the utilization of potential substrate found in cultures are also applicable to bacteria as they exist in seawater. The sensitivity of the assays may be enhanced by concentrating seawater assemblages of bacteria or radiolabeling them (e.g. with tritiated leucine) prior to osmotic shock.

Possible significance of periplasmic aminopeptidase and APase for substrate processing. Our finding that the majority of extracytoplasmic aminopeptidase in S8 was in the periplasmic space is consistent with the hypothesis that processing in the periplasm plays an important role in protein utilization. While the present study was not intended to determine the specific roles of the cell surface and periplasmic aminopeptidases, we speculate that the cell surface aminopeptidases are endohydrolases while the periplasmic aminopeptidases are exohydrolases. The surface aminopeptidases would act on 
Table 7. Inhibition of alkaline phosphatase (APase) activity of S8 by $P$, and glucose $6-P$ (G6P). Enzyme activities are given as amol MUF produced cell ${ }^{-1} \mathrm{~h}^{-1}$ APase activity was measured on intact samples and supplemented with $\mathrm{P}_{1}$ (as $\mathrm{Na}_{2} \mathrm{HPO}_{4}$ ) or G6P simultaneously to the addition of MUF-P

\begin{tabular}{|lccc|}
\hline Inhibitor & \multicolumn{2}{c}{$\begin{array}{c}\text { Enzyme activity } \\
\text { Control }\end{array}$} & \% Inhibition \\
\hline$P_{1}(50 \mu \mathrm{M})$ & 235 & 129 & 45 \\
$P_{1}(100 \mu \mathrm{M})$ & 235 & 90 & 62 \\
G6P $(5 \mathrm{mM})$ & 251 & 32 & 87 \\
G6P $(5 \mathrm{mM})$ & 262 & 28 & 89 \\
\hline
\end{tabular}

environmental protein to generate oligomers while the periplasmic aminopeptidases would hydrolyse the oligopeptides into amino acids. In this model amino acids would be produced in an environment (periplasmic spacel where ihey may interact with substrate binding proteins or directly with the permeases. Lee \& Merkel (1981) found that 2 periplasmic protease in Alteromonas B-207 were aminopeptidases.

There was a dramatic difference between the susceptibility of periplasmic aminopeptidase and APase of S8 to cold osmotic shock (above). Most APase but only a very small fraction of aminopeptidase was shockable. This difference may indicate differences in the interactions of the 2 enzyme activities with the periplasmic environment. For instance, the aminopeptidase may be associated with the cytoplasmic membrane components while the APase might occur more freely.

Implications for ectoenzyme studies in marine environment. Our results, while they do not contradict it, are not conclusive in testing whether APase was solely in the periplasmic space. Most APase was shockable; $\sim 65 \%$ was released by the first shock and a further $-15 \%$ was released by a second shock. Whether the remaining $20 \%$ was surface-bound or periplasmic but not shockable cannot be determined from our results. If APase was restricted to the periplasmic space it would support the hypothesis that low-molecularweight potential substrates are processed largely within the periplasmic space.

Our results have implications for the methodology of ectoenzyme measurements in natural assemblages of marine bacteria. The great sensitivity of fluorogenic conjugates of MUF and AMC has been a boon in studies of ectoenzymes in seawater samples. Enzyme assays can be performed with ease and require short incubations. However, a long standing uncertainty has been whether these fluorogenic substrates might penetrate the cytoplasmic membrane. If they did then they would not measure ectoenzyme activities as distinguished from cytoplasmic activities. The 'good news' from the present study is that the fluorogenic substrates do not appear to measure cytoplasmic enzyme activities. The 'bad news' is that the fluorogenic substates do enter the periplasm and consequently the measurements include both cell surface and periplasmic activities. Actually, this need not be a problem. In environmental studies we should define the ectoenzyme activity to include both the cell surface and the periplasmic pools (e.g. Priest 1984). Indeed, additional insight regarding the role of ectoenzymes in nutrient processing may be obtained if we measured both pools but could distinguish between them. This should be possible with competition protocols of the type employed here. Such analysis could test, for instance, whether there is a regulatory relationship between enzyme activities in the 2 pools. For example the relative stabilities and synthesis rates of the periplasmic and cell surface ectoenzymes may be different. Such issues of enzyme regulation will eventually be resolved in order to develop a biochemical framework for bacteria-organic matter interactions. In the short term, we suggest that studies of environmental measurements of ectoenzymes should attempt to make an operational distinction between the 'surface ectoenzymes' and 'periplasmic ectoenzymes'.

Acknowledgements. We thank D. C. Smith and G. F. Steward for valuable comments on the manuscript. J.M. was supported by a Spanish government fellowship (Ref. PF91 38495763). This research was supported by US NSF and ONR grants to F.A.

\section{LITERATURE CITED}

Albertson, N. H., Nyström, T., Kjelleberg, S. (1990a). Exoprotease activity of two marine bacteria during starvation. Appl. environ. Microbiol. 56: 218-223

Albertson, N. H., Nyström, T., Kjelleberg, S. (1990b) Starvation-induced modulations in binding proteindependent glucose transport by the marine Vibrio sp. S14 FEMS Microbiol. Lett. 70: 205-210

Ames, G. F.-L., Prody, C., Kustu, S. (1984). Simple, rapid and quantitative release of periplasmic proteins by chloroform. J. Bacteriol. 160: 1181-1183

Ammerman, J. W., Azam, F. (1985). Bacterial 5'-nucleotidase in aquatic ecosystems: a novel mechanism of phosphorus regeneration. Science 227: $1338-1340$

Ammerman, J. W., Azam, F. (1991). Bacterial 5'-nucleotidase activity in estuarine and coastal marine waters: characterization of enzyme activity. Limnol. Oceanogr. 36 $1427-1436$

Billen, G. (1991). Protein degradation in aquatic environments. In: Chróst, R. J. (ed.) Microbial enzymes in aquatic environments. Springer-Verlag, New York, p. 123-143

Calcott, P. H., Macleod, R. A. (1975). The survival of Escherichia coli from freeze-thaw damage: permeability barrier damage and viability. Can. J. Microbiol. 21 $1724-1732$

Chróst, R. (1989). Characterization and significance of $\beta$. glucosidase activity in lake water. Limnol. Oceanogr. 34 $660-672$ 
Chróst, R. J. (1990). Microbial ectoenzymes in aquatic environments. In: Overbeck, J., Chróst, R. J. (eds.) Aquatic microbial ecology: biochemical and molecular approaches. Brock/Springer, New York, p. 47-78

Chróst, R. J. (1991). Environmental control of the synthesis and activity of aquatic microbial ectoenzymes. In: Chróst, R. J. (ed.) Microbial enzymes in aquatic environments. Springer-Verlag, New York, p. 29-59

Chróst, R., Wcislo, R., Halemejko, G. (1986). Enzymatic decomposition of organic matter by bacteria in a eutrophic lake. Arch. Hydrobiol. 107 145-165

Chróst, R., Overbeck, J. (1987). Kinetics of alkaline phosphatase activity and phosphorus availability for phyto. plankton and bacterioplankton in Lake Plußsee (North German eutrophic lake). Microb. Ecol. 13: 229-248

Geesey, G. G., Morita, R. Y (1981). Relationship of cell envelope stability to substrate capture in a marine psychrophilic bacterium. Appl. environ. Microbiol. 42: $533-540$

Hollibaugh, J. T., Azam, F. (1983). Microbial degradation of dissolved proteins in seawater. Limnol. Oceanogr. 28: $1104-1116$

Hoppe, H.-G. (1983). Significance of exoenzymatic activities in the ecology of brackish water: measurements by means of methylumbelliferyl-substrates. Mar. Ecol. Prog. Ser. 11: $299-308$

Hoppe, H.-G. (1991). Microbial extracellular enzyme activity: a new key parameter in aquatic ecology. In: Chróst, R. J. (ed.) Microbial enzymes in aquatic environments. Springer-Verlag, New York, p. 60-83

Hoppe, H.-G., Kim, S.-J., Gocke, K. (1988). Microbial decomposition in aquatic environments: combined process of extracellular enzyme activity and substrate uptake. Appl. environ. Microbiol. 54: 784-790

Kim, J., ZoBell, C. E. (1974). Occurrence and activities of cellfree enzymes in oceanic environments. In: Colwell, R. R. Morita, R. Y (eds.) Effect of the ocean environment on microbial activities. University Park Press, London, p. $368-385$

Lancelot, C., Billen, G., Mathot, S. (1989). Ecophysiology of phyto- and bacterioplankton growth in the Southern Ocean. Belgian Scientific Research Programme on Ant-

This article was submitted to the editor arctica. In: Caschetto, S. (ed.) Plankton ecology, Vol. 1 Science Policy Office, Brussels

Lee, C. C. T., Merkel, J. R. (1981). Selective release and purification of two periplasmic Alteromonas B-207 aminopeptidases. Biochim. biophys. Acta 661.39-44

Little, J., Sjogren, R., Carson, G. (1979). Measurement of proteolysis in natural waters. Appl. environ. Microbiol. 37: 900-908

Meyer-Reil, L.-A., Bölter, M., Dawson, R., Liebezeit, G., Szwerinski, H., Wolter, K. (1981). Enzymatic decomposition of proteins and carbohydrates in marine sediments: methodology and field observation during spring. Kieler Meeresforsch., Sonderh. 5: 311-317

Neu. H. C., Heppel, L. A. (1965). The release of enzymes from Escherichia coli by osmotic shock and during the formation of spheroplasts. J. biol. Chem. 240: 3685-3692

Porter, K. G., Feig, Y. S. (1980). The use of DAPI for identifying and counting aquatic microflora. Limnol. Oceanogr. 25: $943-948$

Priest, F. G. (1984). Extracellular enzymes. Van Nostrand Reinhold, Wokingham

Rehnstam, A. S., Backmam, S., Smith, D. C., Azam, F., Hagström, $\AA$. (1993). Blooms of sequence-specific culturable bacteria in the sea. FEMS Microbiol. Ecol. (in press)

Rodgers, H. (1961). The disimilation of high molecular weight subtances. In: Gunsalus, I., Stanier, R. (eds.) The Bacteria. Academic Press, New York, p. 261-318

Rosso, A. L., Azam, F. (1987). Proteolytic activity in coastal oceanic waters: depth distribution and relationship to bacterial populations. Mar. Ecol. Prog. Ser. 41: 231-240

Smith, P. K., Krohn, R. I., Hermanson, G. T., Mallia, A. K., Gartner, F. H., Provenzano, M. D., Fujimoto, E. K., Goeke, N. M., Olson, B. J., Klenk, D. C. (1985). Measurement of proteins using bicinchoninic acid. Analyt. Biochem. 150: $76-85$

Somville, M., Billen, G. (1983). A method for determining exoproteolytic activity in natural waters. Limnol. Oceanogr. 28: $190-193$

Vives Rego, J., Billen, G., Fontigny, A., Somville, M. (1985). Free and attached proteolytic activity in water environments. Mar. Ecol. Prog. Ser. 21: 245-249

Manuscript first received: August 31, 1992

Revised version accepted: November 24, 1992 